GLOBAL JOURNAL OF GEOLOGICAL SCIENCES VOL. 14, 2016: 87-95

\title{
STABILIZATION OF DREDGED SPOILS FOR PAVEMENT CONSTRUCTION IN THE NIGER DELTA, NIGERIA
}

\section{OGHENEKOME OFUDU, AKAHA C. TSE AND ENUVIE G. AKPOKODJE}

(Received 14 December 2015; Revision Accepted 5 February 2016)

\begin{abstract}
Natural soils underlying the East-West road are mainly clay and silt of poor quality as subgrade and subbase materials. However, dredged fine grained sandy soils stockpiled at river banks along the road as wastes may be modified for strength gain to replace the excavated natural soil during road construction. The optimum stabilization conditions of the dredged soils were determined in this study to evaluate the strength improvement for beneficial use as road construction materials in view of their large quantity and nearness to the point of use. The laboratory tests carried out on the dredged soils included particle size distribution, compaction and California Bearing Ratio. Cement stabilization was performed on the dredged spoil. Results of the particle size distribution analysis showed that about $80 \%$ of the natural soils, but less than $2 \%$ of the dredged spoil particles are finer than $0.075 \mathrm{~mm}$. The moisture content and plasticity indices of the natural soils are 37 to $57 \%$ and 21 to $33 \%$ respectively. They are A-7-6 to A-6-7 soils which indicate poor quality as subgrade materials. Tests on the dredged sand revealed the following range of geotechnical properties: coefficient of uniformity, 2.21 - 2.89; coefficient of gradation, 1.11 - 1.28; maximum dry density, $1.79-1.84 \mathrm{~g} / \mathrm{cm}^{3}$; optimum moisture content, $14-15 \%$; and CBR of $17-20 \%$. To improve the engineering properties and hence suitability in pavement construction of the spoils, 4 to $7 \%$ addition of cement for stabilization resulted in significant strength increase, with optimum results obtained on addition of $6 \%$ cement. The natural soils constitute very poor pavement construction materials based on their index properties. They may be excavated and replaced with the dredge spoils which must be stabilized before use.
\end{abstract}

KEYWORDS: Stabilization, dredge spoil, pavement, Niger Delta, cement

\section{INTRODUCTION}

The failure of flexible highway pavements is a common phenomenon which manifests by the development of minor potholes, road settlement, rutting and unevenness. While a number of contributory causes have been identified, such as misuse, overuse or poor construction (Ajayi 1982), the majority of the road failure in the tropics has been attributed to geotechnical factors (Adeyemi and Oyeyemi 1992). The East-West road (Fig. 1) in southern Nigeria runs across the Niger Delta, a wetland which has peculiar environment, geomorphology and soil characteristics. The very low water gradient, the flat topography, the poor engineering properties of the silty and clayey foundation soils, and the high rainfall during the wet season which ranges from $200 \mathrm{~mm}$ inland and over $4000 \mathrm{~mm}$ at the coast, all combine to create serious drainage and engineering problems (Akpokodje 2001). Seasonally flooded swamps constitute more than $60 \%$ of the Niger Delta. The general swampiness of the terrain constitute formidable constraint to civil engineering constructions. Engineering design of the East-West road provides for an alignment that crosses almost 60 water bodies requiring bridges and extensive removal of the natural soils due to high silt and clay content, poor geotechnical properties and very poor quality as subgrade materials.
Dredging of the rivers along the road alignment generates large quantities of spoils. As a result, tons of dredged materials which are unsuitable for the original intended use, are considered as wastes, and are stockpiled over bank upon fringing mangroves because disposal in open water bodies is prohibited. One of the challenges is to find economical and environmentally suitable means to reuse the soils in engineering infrastructure including road construction. Beeghly and Schrock (2010) have shown that dredged soil is commonly used to replace weak soils for various engineering constructions including maintenance of waterways, road transportation infrastructure, reclamation and soil improvements. However, dredged spoils in their natural state are weak and need conditioning for road construction and may contain contaminants which have direct or indirect environmental impacts if not properly managed (Baxter et al. 2006). The environmental problems associated with abandoned spoils include extreme acidification, heavy metal pollution, and general habitat degradation that prevents the re-colonization of the disposal sites by native species (Ohimain et al. 2004). Thus one way to prevent, reduce or remove adverse environmental degradation caused by the dredged materials is to put them into beneficial use in construction. Results of studies by Dermatas et al. (2003), Gaffney and Gorleski,

Oghenekome Ofudu, Department of Geology, University of Port Harcourt, Port Harcourt, Rivers State, Nigeria.

Akaha C. Tse, Department of Geology, University of Port Harcourt, Port Harcourt, Rivers State, Nigeria.

Enuvie G. Akpokodje, Department of Geology, University of Port Harcourt, Port Harcourt, Rivers State, Nigeria. 
(2005) and Nontananandh et al. (2011) show that altering the chemical and physical composition of the spoils by stabilization produces a 'conditioned' soil mix with improved strength properties suitable for use in civil engineering construction.

In view of the large volumes of sand dredged from rivers along the East-West road alignment, it is thought that a beneficial scheme to use such large quantity of otherwise waste material is to re-use it in sub-base construction. Its nearness to point of use, is an important consideration that saves cost. Dredged spoils stabilized with cement or lime are used in the construction of road bases and sub-bases, for the treatment of subgrade soils and also for slope protection, dam and embankments slopes and backfill around pipes and retaining walls (Daniels and Whittecar, 2006). It has good compressive and shear strength, but is brittle and has low tensile strength, so it is prone to forming cracks.

The purpose of this work is to determine the optimum conditions for the stabilization of the large quantity of dredged soil which is considered as waste, but may be used for constructing the road sub-base if it is reconditioned to improve its engineering attributes.

\section{DESCRIPTION OF STUDY AREA}

The study area is that part of the East-West Road between Warri and Kaima (Fig. 2) which lie between latitudes $5^{\circ} 30^{\prime}$ and $6^{\circ} 37^{\prime}$ North and longitudes $6^{\circ} 17^{\prime}$ and $6^{\circ} 47^{\prime}$ East. The East-West road is designed to run through 664 coastal communities from Epe in Lagos to Calabar across the Niger Delta, which is a wetland. Although the Niger Delta region is home to 26 $\%$ of Nigeria's population, it holds only $17.6 \%$ of the country's length of roads due to peculiar environment, geomorphology and soil characteristics. It is drained and criss-crossed by a network of river distributaries and constitutes an extensive plain exposed to periodic inundation by flooding when the rivers and creeks overflow their banks. The area is characterised by widespread and irregular distribution of weak soils responsible for foundation problems in houses, embankments and roads.

Geologically, the area is underlain by the Benin Formation which consists of continental deposits of Miocene to Recent sand associated with freshwater swamps, backswamps and meander belt of flat to subhorizontal elevation (Etu-Efeotor and Akpokodje, 1990; Allen, 1965). Various types of geomorphological units and depositional environments have been recognized in the area from the coast landwards. These include active/abandoned coastal beaches, saltwater and freshwater mangrove swamps, deltaic plain alluvium and meander belt, dry deltaic plain with abundant freshwater swamps, and dry flat land and plain (Fig. 3). The major soil types are light to dark grey, fine sand to silty clay. Data from the nearest meteorological station in Warri shows that the average annual rainfall is about $3500 \mathrm{~mm}$ (Department of Meteorological services, 2009).

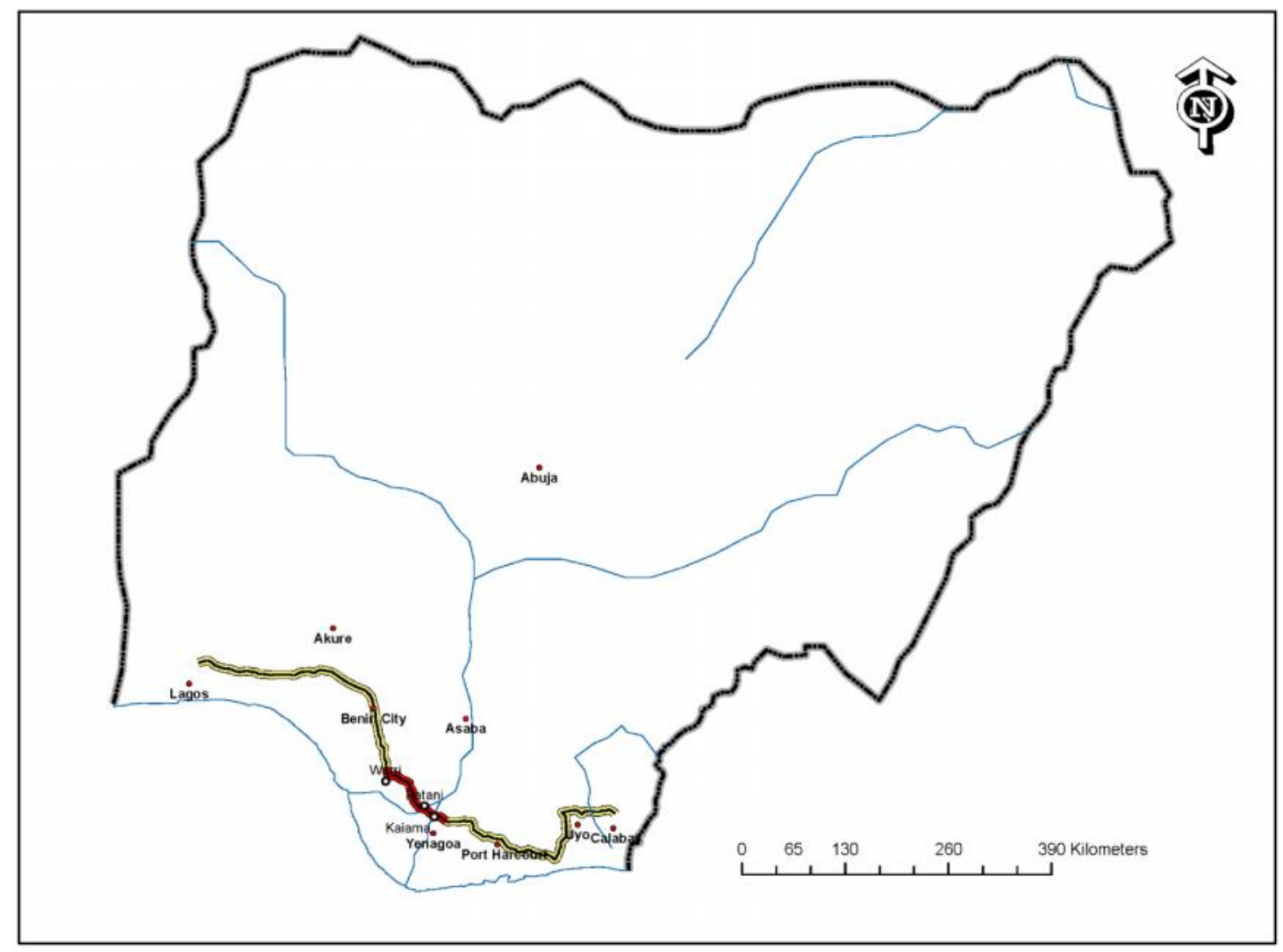

Figure 1: Map of Nigeria Showing the East -West Road 


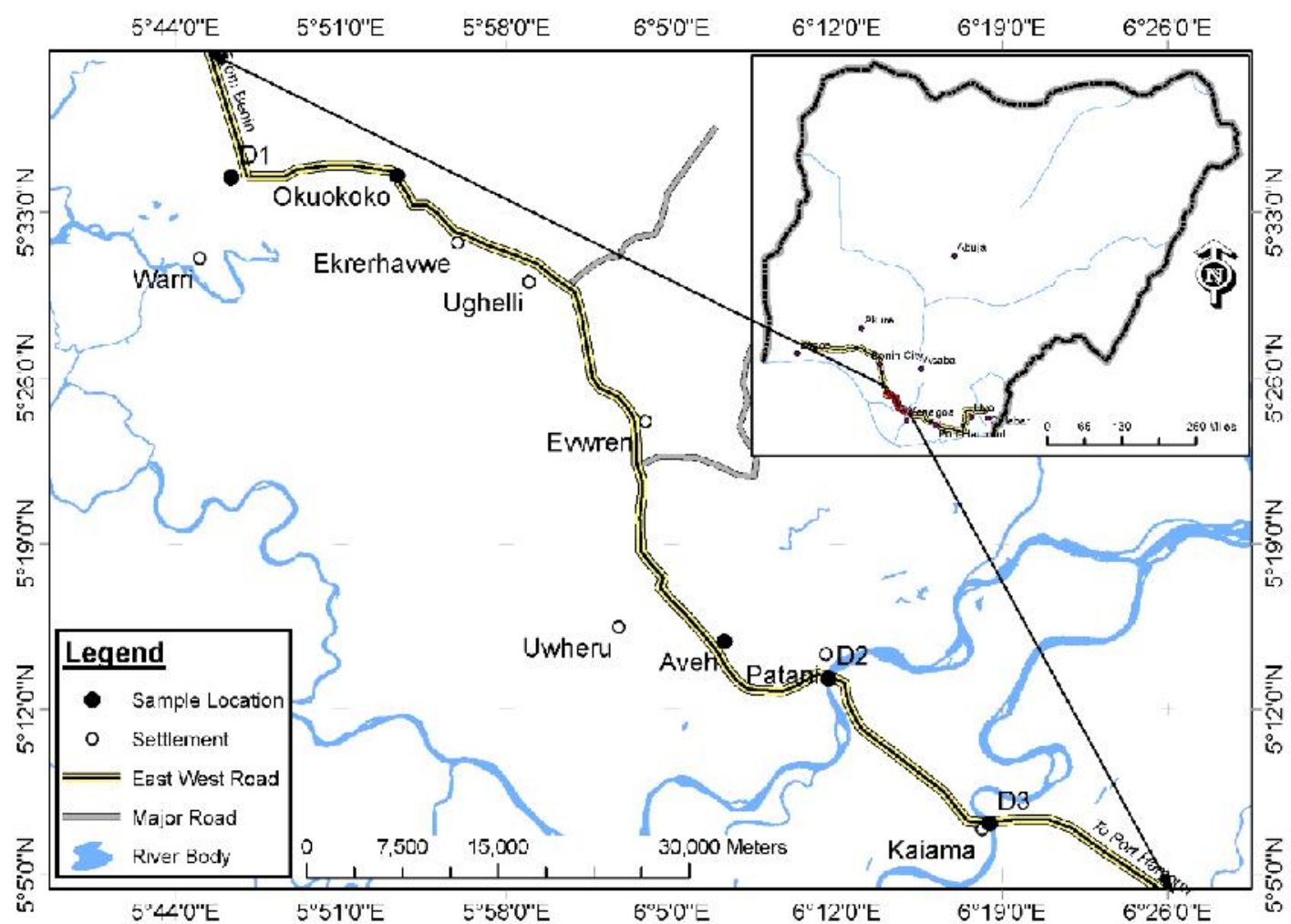

Figure 2: Section of the studied East-West Road showing sampling points

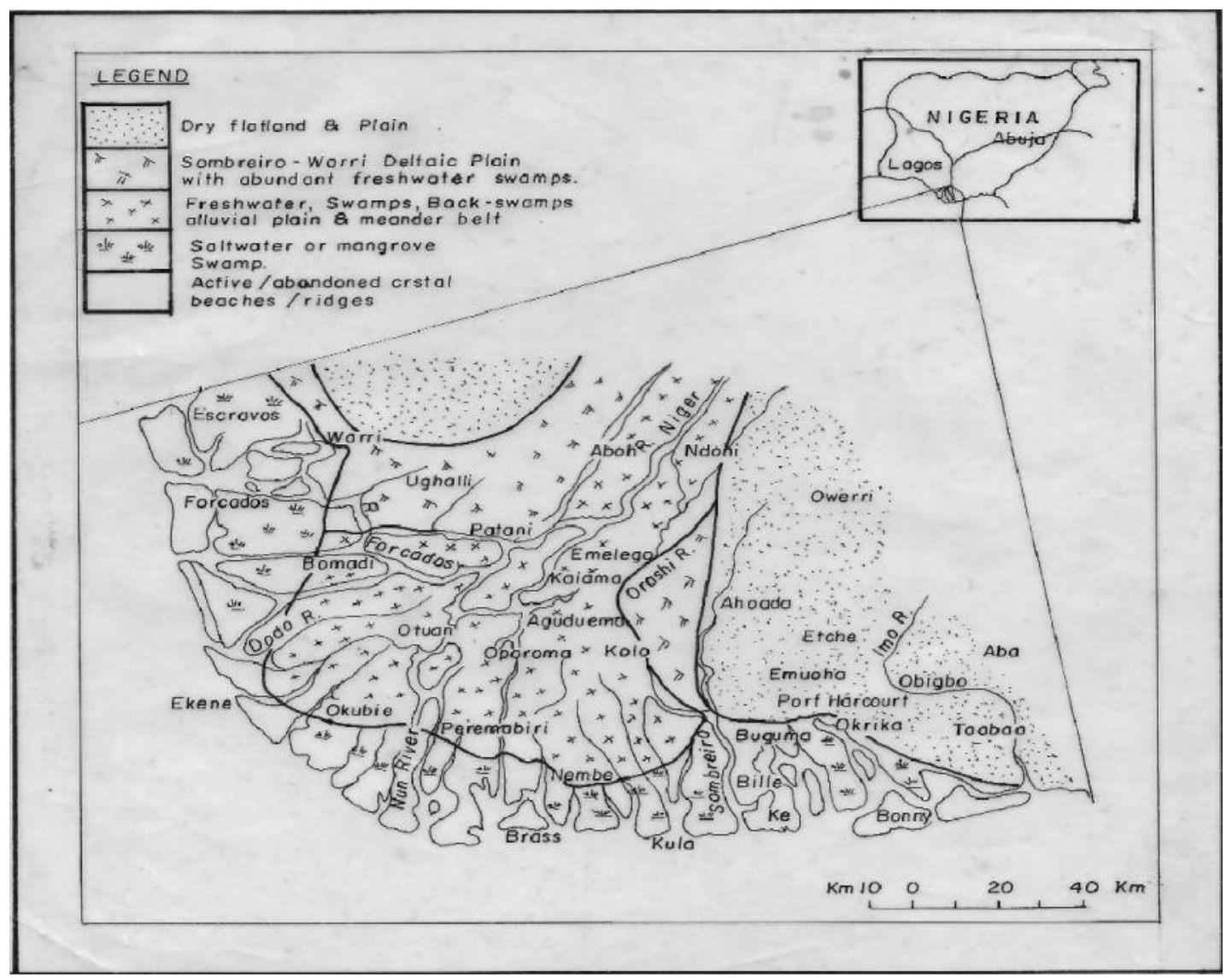

Figure 3: Major geomorphologic zones of the Niger Delta (Allen 1965) 


\section{METHOD OF STUDY}

During field study, nine disturbed samples of the natural soil were collected in $1 \mathrm{~m}$ deep test holes, three each at Okuokoko, Aveh and Patani. Similarly, three soil samples each were obtained from three major dredged spoil stockpiles (Fig. 4) at Warri, Patani, and Kaiama labelled $\mathrm{a}, \mathrm{b}$ and $\mathrm{c}$ respectively. The sample locations and co-ordinates are shown in Fig. 2 and Table 1 respectively. Laboratory tests, including moisture content, Atterberg limits, particle size distribution by wet and dry sieve analyses and the density-moisture relationship using modified American Association of State Highway Officials (AASHO) compaction were performed according to procedures specified by BS 1377 (1990). Unsoaked California Bearing Ratio (CBR) tests were performed on the natural soil samples using the OMC obtained from the compaction test. The engineering classification of the soils was carried out based on texture and plasticity. The untreated dredged soil materials were in their liquid limit state therefore undrained shear strength could not be measured. However, their textural properties were determined by sieve analysis.

Stabilization was performed to determine the optimum conditions necessary to improve the strength of the dredged soils for beneficial use in pavement construction. Triplicate trial mixes were prepared with $4 \%, 5 \%, 5.5,6 \%$ and $7 \%$ by wet weight of Type 1 normal Portland cement added to the dredge materials at three different water contents of 45,60 and $75 \%$. The compacted sand-cement mixtures were waxed and cured for six days and then soaked for $24 \mathrm{hrs}$ before they were tested in CBR machine. Portland cement of all types is widely used for stabilizing different soil types including low-plasticity clays and sandy soils to improve the engineering properties of strength and stiffness.
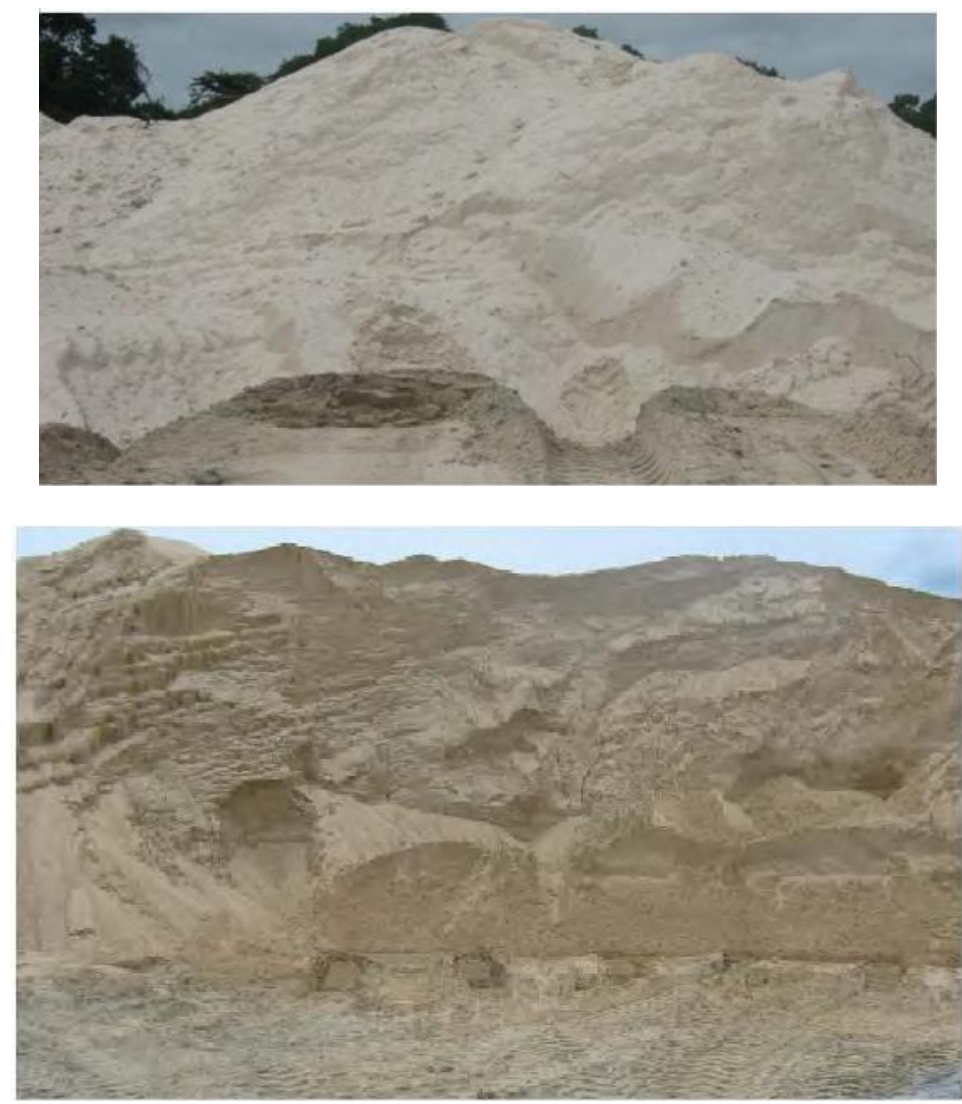

b

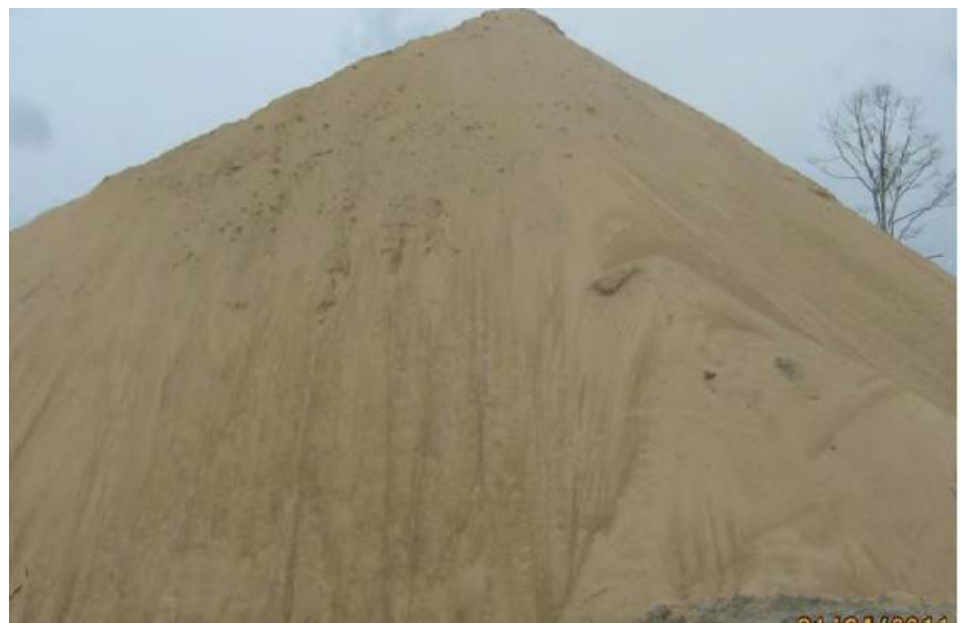

Figure 4: Dredged material stockpiles at (a) Warri ( b) Patani (c) Kaiama 
Table 1: Coordinates of the sample locations

\begin{tabular}{llll}
\hline Location & Sample & Longitude & latitude \\
\hline Okuokoko & 1 & 5.868072 & 5.580450 \\
& 2 & 5.870132 & 5.577033 \\
\multirow{3}{*}{ Aveh } & 3 & 5.875625 & 5.576350 \\
& 4 & 6.131057 & 5.214040 \\
\multirow{4}{*}{ Patani } & 5 & 6.132431 & 5.214040 \\
& 6 & 6.133117 & 5.212673 \\
& 8 & 6.18461 & 4 \\
& 9 & 6.186676 & 5.224981 \\
& 6.188735 & & 5.227716 \\
\hline
\end{tabular}

\section{RESULT S AND DISCUSSION}

\section{In situ-soils}

The natural soil is composed of mainly silty clay and sand. Particle size distribution results (Fig. 5) show that the soils are made up of 9 to $23 \%$ sand and 81 to $87 \%$ fines. The high proportion of silty clay fraction implies a low permeability potential, which will make the soil undergo a considerable amount of compressibility when used in road construction, and render it unsuitable as subgrade or sub-base materials. The engineering properties are summarized in Table 2.

With a coefficient of uniformity (CU) of 2 to 3 , the soils are classified as SP (poorly graded) on the Unified Soil Classification (USC) scheme. Generally, poorly graded soils do not achieve high dry density when compacted and therefore do not constitute good construction materials. The liquid limit and plasticity index range from 60.0 to $75.8 \%$ and 21.0 to $32.5 \%$ respectively. The soils plot below the $A$-line of the plasticity chart (Fig. 6), and classify as organic clay of high plasticity, $\mathrm{OH}$. This classification is supported by the high liquid limit of the soils which is greater than $50 \%$ in all the samples. According to civil engineers, a soil suitable for use as an engineered construction material should have a liquid limit (LL) less than $45 \%$ and a plasticity index (PI) less than 20\% (Beeghly and Schrock 2010). The Federal Ministry of Works (1997) specifications for the design of both sub-base and base course materials recommends that liquid limit and plasticity index of soils should not be greater than $30 \%$ and $12 \%$ respectively. These values are exceeded by the study soil samples. The natural soils fall into the A-75 to A-7-6 class of the AASHTO classification system, indicating very poor quality as sub-grade or sub base materials. Generally, the higher the plasticity index, the greater the engineering problems that would be associated with the soil when used as an engineering material for foundations and road pavement etc.

The textural characteristics of in-situ soils often influence foundation design and ground water drainage. Poorly graded sands are more likely to have better drainage than a well graded soil because there are more void spaces in a poorly graded soil. However, a well graded soil is able to be compacted more than a poorly graded soil. The poor engineering properties of the natural soils imply that if used as subgrade or subbase materials, they will not withstand stresses generated by axial loading of the road from vehicular traffic. This will result in pavement distress and failure. The best engineering option is to remove the soil and replace it with more suitable earth materials for sustainable pavement performance and longevity.

\section{Dredged materials}

Unlike the natural soils which have a very high percentage of fines ( 81 to $87 \%$ ), the dredged soils consist of over $95 \%$ whitish to yellowish sand with subordinate silt and clay fractions. Particle size distribution curves (Fig. 7) indicate that the sand is fine to medium grained. The engineering properties are summarized in Table 3 . The effective diameter $\left(D_{10}\right)$, and coefficient of uniformity $\left(C_{U}\right)$ range from 0.19 to 0.22 $\mathrm{mm}$ and 2 to 3 respectively, indicating that the sands are uniformly graded. The coefficient of curvature (Cc) values fall between 1.11 and 1.28. A soil is said to be well graded if CC lies between 1 and 3 (Murthy, 2008). Using these textual parameters, the sands are rated as A-4 on the AASHTO soil classification scheme, indicating poor to moderate quality as pavement materials.

\section{Soil Stabilisation}

In order to improve upon the strength and stiffness of the dredged materials for use in road construction, physical stabilisation by compaction and chemical stabilization by addition of cement to the soil were attempted. Compaction of sub grade soils is a fundamental geotechnical operation in road projects. The purpose of compaction is generally to enhance the strength or load-carrying capacity of the soil, while minimizing long-term settlement potential. It also increases stiffness, strength, and reduces swelling potential for expansive soils, and the detrimental effects of water. The results of the standard Proctor compaction test (Fig. 8) showed that values of maximum dry density (MDD) and optimum moisture content (OMC) range from 1.79 to $1.84 \mathrm{~g} / \mathrm{cm}^{3}$ and 13.9 to $14.9 \%$ respectively.

For a soil to be used as good backfill material, the Federal Ministry of Works (1997) recommends that the value of MDD should fall between 1.70 and 1.90 $\mathrm{kg} / \mathrm{m}^{3}$ while the OMC should be between values of 7 and $15 \%$ for both sub-base and base-course materials. The results for the dredged soil fall within these ranges and therefore satisfy the recommended limits, 


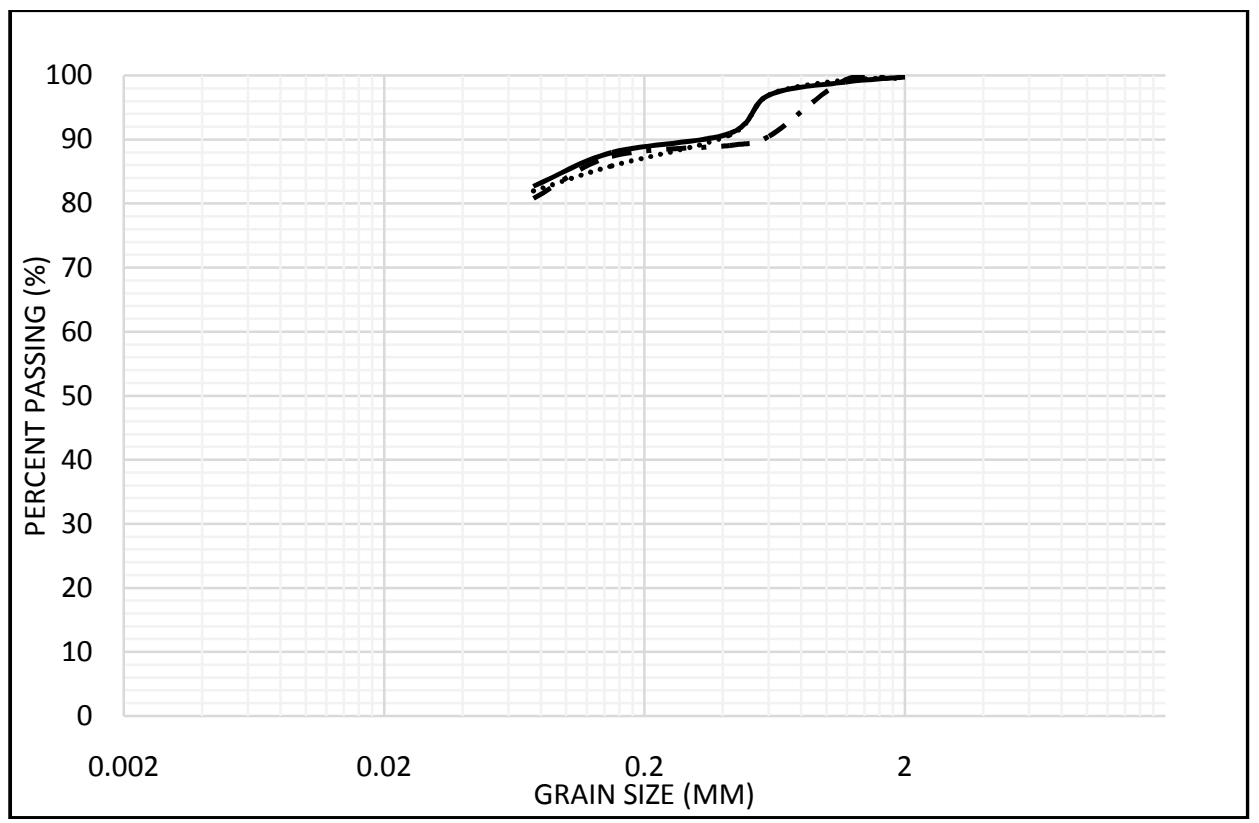

Figure 5: Gradation envelope of the natural soils

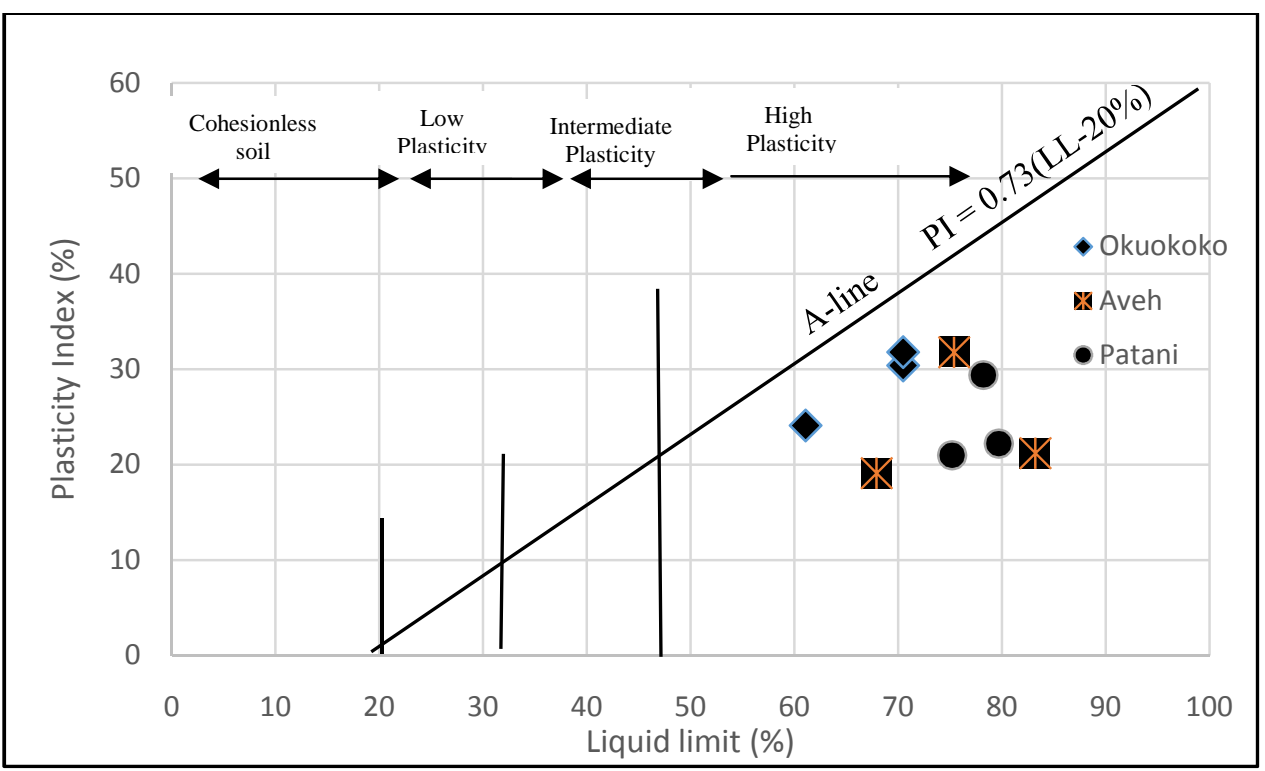

Figure 6: Position of the natural soils on the plasticity chart 


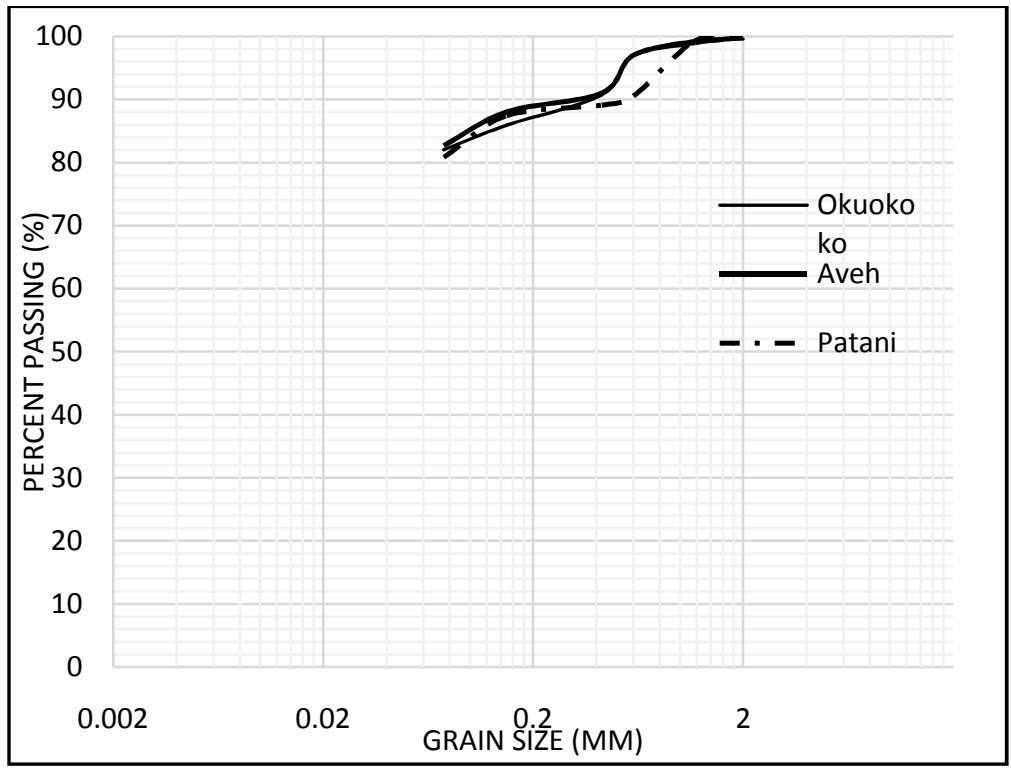

Figure 7: Gradation envelope of the dredged soils

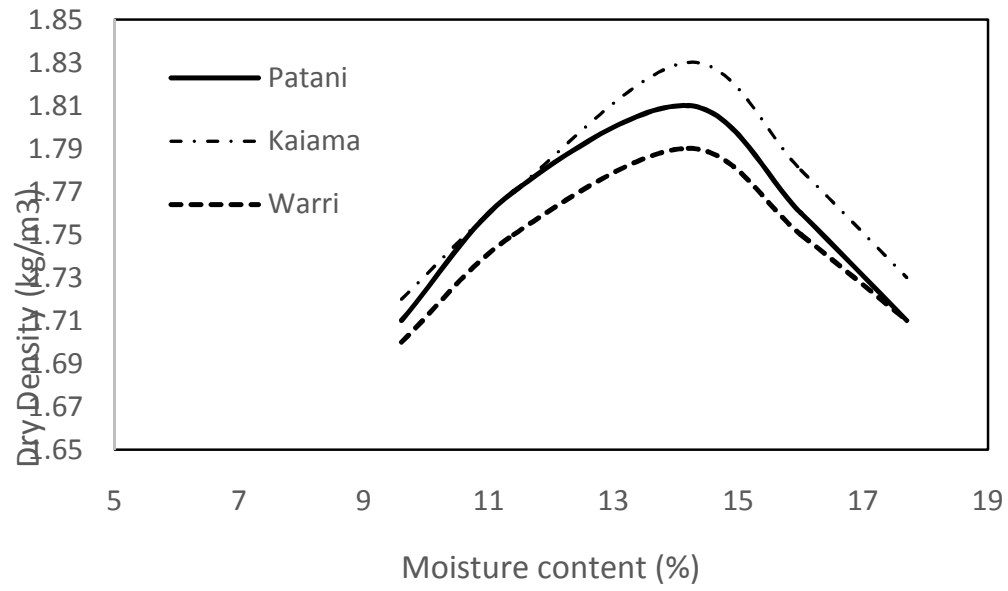

Figure 8: Moisture- Density relationship of dredged soils

hence, they are fairly suitable materials for road construction. The soaked CBR values of the untreated dredged sand range from $17-20 \%$ with an average of approximately $19 \%$ compared to $20-30 \%$ recommended for sub-grade and above $30 \%$ for sub-base materials. Therefore, the dredged sands are barely suitable materials for sub-grade, but poor as sub-base materials.

Stabilisation was attempted to improve the strength properties of the dredged spoil, especially the CBR by formulating soil-cement mix ratios and defining the optimum quantity and proportion that will chemically react and improve strength. The values of CBR obtained with the addition of 4 to $7 \%$ cement ranged from 118 to $209 \%$ (Table 4). From the results, it is implied that addition of $6 \%$ cement to the dredged spoil is optimum to stabilize the fine sediments. This is similar to results obtained by Wang et al. (2012). This shows that addition of cement results in an increase in CBR, which implies an increase in the strength of the material. Thus the CBR requirements for base course materials were met when cement

was

Table 2: Index properties of the natural soils

\begin{tabular}{|c|c|c|c|c|c|c|c|c|c|c|c|}
\hline Location & W (\%) & & Liquid Lin & $\%)$ & Plastic lim & (\%) & $\begin{array}{l}\text { Plasticity } \\
(\%)\end{array}$ & Index & $\begin{array}{l}\% \text { finer } \mathrm{t} \\
0.075 \mathrm{mn}\end{array}$ & han & $\begin{array}{l}\text { USC } \\
\text { Classification }\end{array}$ \\
\hline & Range & $\mathrm{Av}$ & Range & $\mathrm{Av}$ & Range & Av & Range & $\mathrm{Av}$ & Range & $\mathrm{Av}$ & \\
\hline Ok & 43.6 & 51.4 & $75.4-75.8$ & 75.23 & $43.6-45.0$ & 44.27 & $31.0-32.5$ & 31.77 & 79.5-89.6 & 83.7 & $\mathrm{OH}$ \\
\hline Aveh & $37.0-40.0$ & 39.0 & $60.0-61.1$ & 60.70 & $37.0-38.1$ & 37.53 & 24. $0-25.8$ & 24.80 & $80.5-82.2$ & 81.5 & $\mathrm{OH}$ \\
\hline Patani & $48.8-57.6$ & 53.5 & $74.5-75.2$ & 74.90 & $54.2-55.0$ & 54.63 & $21.0-22.1$ & 21.80 & $86.4-89.1$ & 87.4 & $\mathrm{OH}$ \\
\hline
\end{tabular}

$\mathrm{W}=$ Natural Moisture content (\%), Av = average 
Table 3 Summarizing engineering properties of the dredged sand

\begin{tabular}{|c|c|c|c|c|c|c|c|c|c|c|c|c|c|}
\hline \multirow[t]{2}{*}{ Location } & \multicolumn{7}{|c|}{$\%$ Passing sieve diameter $(\mathrm{mm})$} & \multicolumn{3}{|c|}{ Size parameters $(\mathrm{mm})$} & \multicolumn{2}{|c|}{ Compaction } & \multirow{2}{*}{$\begin{array}{l}\text { CBR } \\
\text { Soaked }\end{array}$} \\
\hline & 2.00 & 1.18 & 0.60 & 0.425 & 0.30 & 0.15 & 0.075 & $D_{10}$ & $\mathrm{D}_{60}$ & $\mathrm{Cu}$ & $\begin{array}{l}\text { MDD } \\
\left(\mathrm{g} / \mathrm{cm}^{3}\right)\end{array}$ & $\begin{array}{l}\text { OMC } \\
(\%)\end{array}$ & \\
\hline Okuokoko & 100 & 97.1 & 66.6 & 42.6 & 23.3 & 4.5 & 1.6 & 0.19 & 0.55 & 3 & 1.79 & 14.2 & 19 \\
\hline Patani & 100 & 97.8 & 76.1 & 60.1 & 24.7 & 4.8 & 2.3 & 0.19 & 0.42 & 2 & 1.81 & 13.9 & 17 \\
\hline Kaiama & 100 & 98.4 & 81.6 & 45.7 & 17.9 & 2.5 & 1.2 & 0.22 & 0.49 & 2 & 1.84 & 14.9 & 20 \\
\hline
\end{tabular}

added to the dredged sand. The higher the CBR value of a particular soil, the more strength it has to support the pavement. A thinner pavement structure could be used on a soil with a higher CBR value than on a soil with a lower CBR value.

Increasing the cement content increases the quality of the mixture. At low cement content, the product is generally termed cement-modified soil. At higher cement contents, the end product is termed soilcement or cement-treated base, sub-base, or subgrade. FHWA (2005) explains that stabilizing the dredged material with cement binds the small particles together, improves the cohesive shear strength and increases the difficulty with which particles can move into a denser packing under load. Cement when used as subgrade stabilizing agent partially fills the voids between the soil particles, thus reducing the pathways for water to move through the soil by reducing connected pore spaces and hence the permeability of the soil. Reduction of permeability also creates a waterproof surface to protect underlying, water sensitive soils from the intrusion of surface water. This qualifies the conditioned soil for use as fills in some types of construction processes, including pavement construction. Converting this otherwise waste to beneficial use is in line with the European Union (2005) decision logic for dealing with dredged material. It recommends a variety of purposes to which dredge spoils can be deployed, including use as fill and construction materials, placing the dredged material at specific locations to combat erosion, and manufacturing bricks, etc. These uses will be particularly beneficial given the high rainfall intensity, extensive marsh land and frequent oil spills in the study area.

\section{CONCLUSION}

The objective of the work was to define a cement mix design procedure to stabilize the dredged material which are generally regarded as wastes. The dredged soil, due to nearness to construction sites and thus economy, may be used in road construction if conditioned to achieve desirable strength. This is because the natural soils along the road alignment consist of clays, clayey silts and sands which have low load bearing potentials and cannot be used as sub-grade and sub-base materials in their natural state. Addition of $6 \%$ by weight of cement optimally increased the CBR value of the soil suitably for use in engineering applications such as in pavement construction. This constitutes a beneficial use of the dredged resource material in civil and/or road construction.

\section{REFERENCES}

Adeyemi G. O and Oyeyemi, F., 1992. Geotechnical basis for failure of section of the Lagos-Ibadan Express way South West Nigeria Bulletin of Engineering Geology \& the Environment 59, (1): 39-45.

Ajayi, T. R. A., 1982. Geotechnical Basis Failure of Section of Lagos-lbadan Express way South West Nigeria Bulletin of Engineering Geology \& the Environment 20, 25-31.

Allen, J. R. L., 1965. Late Quaternary Niger Delta and Adjacent Areas: Sedimentary Environments and Lithofacies. American Association of Petroleum Geologists Bulletin, 49, (5): 1965, 549-600.

Akpokodje, E. G., 2001. Introduction to Engineering Geology. Pam Unique Publishing Company Ltd. Port Harcourt. 259.

Baxter, C., King, J., Silva, A., Page, M and Calabretta, V., 2004. Site Characterization of Dredged Sediments and Evaluationof Beneficial Uses. Recycled Materials in Geotechnics Sessions at ASCE Civil Engineering Conference and Exposition Baltimore, Maryland, United States. doi: 10.1061/40756(149)10 Accessed online $15 / 11 / 2015$

Beeghly, J. and Schrock, M., 2010. Dredge Material Stabilization Using the Pozzolanic or SulfoPozzolanic Reaction of Lime By-Products to Make an Engineered Structural Fill. International Journal of Soil, Sediment and Water, Vol. 3 [2010], Iss. 1, Art. 6, p. 1-21. Available at: http://scholarworks.umass.edu/intlissw/vol3/iss1/

British Standard Institute. 1990. Method of Testing Soils for Civil Engineering purposes. BS 1377.

Daniels, W. L and Whittecar, G. R., 2006. Annual Monitoring Report - 2005 - Weanack Dredge Spoil Utilization. Submitted to Va DEQ and PCC 2/15/2006. Available at: http://www.cses.vt.edu/ revegetation/dredgemanu.html

Department of Meteorological services., 2009. Monthly Rainfall Data for Warri Delta State. Ministry of Agriculture and Natural Resources, Asaba Delta State. 
Dermatas, D., Dutko, P., Balorda-Barone, J., and Moon,

D. 2003. Geotechnical Properties of Cement Treated dredged sediment to be used as transportation fill. Proceedings of Third Specialty Conference on Dredging and Dredged Material Disposal, Dredging '02, Orlando, Florida. pp. 1-14 doi:10.1061/40680(2003)139

Etu-Efotor J. O and Akpokodje, E. G., 1990. Aquifer system of the Niger Delta. J. Mining Geol., 26, (2): 279-284.

European Union., 2005. Dredged material and environmental regulationsin the EU. EuDA/050271

FHW., 2005. Geotechnical Aspects of Pavements Reference Manual. Chapter 7.0 Design Details and Construction Conditions Requiring Special Design Attention. Publication No. FHWANHI-05037 Federal Highway Administration, Washington, DC.

Federal Ministry of Works and Housing., 1997. Nigerian General Specification for Roads and Bridges (Revised Edition), 2, 137-275.

Gaffne, D. A. P. E and Gorleski, E. S., 2005. Dewatering and Amending Dredged Materials for Beneficial Use,(doi10.1061/40783(162)17.http://scitation.ai p.org/jhtml/doi.jsp.) 2-8.
Murth, V. N. S., 2008. Textbook of Soil Mechanics and Foundation Engineering. CBS Publishers. New Delhi. 1043p.

Nontannandh, S., Kaewkaorop, $\mathrm{P}$ and Thongdetsri, T., 2011. Stabilization of Seabed Dredged Materials. NCCE 12, VOL.3, p. 406-410

Ohimain, E. I., Andriesse, $\mathrm{W}$ and vanMensvoort, M. E. F., 2004. Environmental impacts of abandoned dredged soils and sediments. Available options for their handling, restoration and rehabilitation. Journal of Soils and Sediments. 4, (1): 59-65.

Wang, D. X., Abriak, N. E., Zentar, R and Xu, W., 2012. Solidification/stabilization of dredged marine sediments for road construction. Environ Technol. 33, (1-3): 95-101. 